from twenty-one to thirty-two years. $10 \mathrm{ml}$. in addition were withdrawn at this time and the serum separated. The blood stood 42 days. During the course of a three-week period following the storage interval, six intravenous injections of 7 -ml. quantities of the blood, two injections per week, were made into the individuals from whom the blood was obtained; that is, each individual was injected with his or her own stored blood. Ten days after the last injection (day 70) $20 \mathrm{ml}$. of blood was withdrawn from each individual; $10 \mathrm{ml}$. was placed in a bottle contcining $A C D$ solution, and the serum was separated from the remainder. Additional samples of blood were withdrawn and placed in $A C D$ solution as the work continued. The blood in $A C D$ solution was kept at $3^{\circ} \pm 1^{\circ} \mathrm{C}$. and the serum samples were frozen at $-18^{\circ} \mathrm{C}$. The blood samples were prepared and handled using precautions to ensure sterility, and no contamination was detected during the course of the experiment. Red cells were obtained for testing by removing some blood from the storage bottle just before a test was carried out, washed three times in saline buffered at $p \mathrm{H} 7 \cdot 3$, and made up to a 1 per cent concentration.

Between days 71 and 77 the following tests were carried out using day 70 serum and day 0 and 70 red cells of the same individual : agglutination tests using saline and serum as diluents, and cells that had been treated with trypsin; hæmolysis test with added complement ; and the Coomb's test with normal and trypsin-treated cells (Coomb's test repeated on day 164). All the tests were negative. A short while later, the opportunity of utilizing the erythrophagocytic test ${ }^{2}$ was made available. In this test the mixture of red cells and serum is added to a slide culture of phagocytic cells obtained from rabbit spleen. After a 30-min. period, fifty phagocytic cells are observed, and the percentage of them which have ingested red cells is referred to as the phagocytic index. Under normal conditions this ranges up to about 10 ; but when the red cells are sensitized by antisera, it is increased to $\mathbf{2 5}$ or more. The results cited were obtained on day 127. In six of the ten individuals, there was a significant increase in the phagocytic index when day 70 serum was mixed with old (day 0 ) red cells. There was no such increase when day 70 serum was mixed with fresh red cells, or when day 0 serum was mixed with old or fresh red cells. When day 70 serum was absorbed with old and with fresh red cells (one volume of serum plus one volume of the respective cells), the phagocytic index was markedly decreased after the single absorption with old red cells but was unchanged after absorption with fresh cells. The results obtained with old red cells are presented in Tablo 1. These results suggest that these six individuals produced antibodies against their own stored red cells.

The antigenic change in stored red cells may be due to an enzyme or enzymes in the blood, perhaps on the red cell itself, that acts on the red cell. The reason why positive results were obtained only with the erythrophagocytic test may be due to (1) the decreased ability of old red cells to react in some serological tests, $(2)$ the production of small amounts of antibody with the particular injection procedure used, and (3) the possibility that the reaction can be detected only with a particular type or types of serological tests. These and related questions are under investigation.

If individuals can be sensitized with stored red cells, the problem of sensitization may have to be
Table 1. Phagooytic Indices of Stored (DAy 0) Red ChLls with SERA

Cells and serum of the same individual were tested. The phagocytic index recorded is the average of duplicate tests, both of which were in the same range in all cases

\begin{tabular}{|c|c|c|c|c|c|}
\hline $\begin{array}{l}\text { Experi- } \\
\text { mental } \\
\text { subject }\end{array}$ & $\begin{array}{l}\text { Normal } \\
\text { rabbit } \\
\text { serum* }\end{array}$ & $\begin{array}{c}\text { Serum } \\
\text { obtained } \\
\text { at start } \\
\text { of ex- } \\
\text { periment } \\
(\text { day } 0)\end{array}$ & $\begin{array}{l}\text { Serum } \\
\text { obtained } \\
\text { after } \\
\text { injection } \\
\text { procedure } \\
\text { (day } 70 \text { ) }\end{array}$ & $\begin{array}{c}\text { Day } 70 \\
\text { serum } \\
\text { absorbed } \\
\text { with day } \\
0 \text { red } \\
\text { cells }\end{array}$ & $\begin{array}{l}\text { Day } 70 \\
\text { serum } \\
\text { absorbed } \\
\text { with } \\
\text { fresh red } \\
\text { cells }\end{array}$ \\
\hline $\begin{array}{l}\text { Increased } \\
\text { P.I. } \\
\text { M. S. } \\
\text { G. G. } \\
\text { M. M. } \\
\text { J. H. } \\
\text { L. C. } \\
\text { R. S. }\end{array}$ & $\begin{array}{r}4 \\
8 \\
12 \\
6 \\
10 \\
13\end{array}$ & $\begin{array}{r}13 \\
3 \\
9 \\
0 \\
6 \\
5\end{array}$ & $\begin{array}{l}29 \\
34 \\
22 \\
27 \\
30 \\
28\end{array}$ & $\begin{array}{r}14 \\
17 \\
3 \\
8 \\
13 \\
16\end{array}$ & $\begin{array}{l}22 \\
31 \\
25 \\
23 \\
22 \\
28\end{array}$ \\
\hline Average & 9 & 6 & 28 & 12 & 25 \\
\hline $\begin{array}{l}\text { No increase } \\
\text { in P.I. } \\
\text { K. R. } \\
\text { G. W. } \\
\text { L. N. } \\
\text { R. B. }\end{array}$ & $\begin{array}{l}3 \\
7 \\
1 \\
9\end{array}$ & $\begin{array}{r}10 \\
13 \\
6 \\
13\end{array}$ & $\begin{array}{r}12 \\
1 \\
6 \\
9\end{array}$ & $\begin{array}{r}7 \\
4 \\
5 \\
11\end{array}$ & $\begin{array}{r}1 \\
9 \\
2 \\
10\end{array}$ \\
\hline Average & 5 & 10 & 7 & 7 & 5 \\
\hline
\end{tabular}

* Used as a control

considered in investigations directed toward preserving blood for longer periods of time than is possible at present. If, for example, a way is found of preserving blood for transfusion for two- or three-month periods and the antigenic changes are not inhibited, the recipient of the old blood may become sensitized to it and have a transfusion reaction with subsequent transfusions of old blood.

This investigation was supported in part by grant $G-3444$ of the National Institutes of Health. The assistance of Dr. James M. McFadden with the injections, and Dr. C. S. Wright and Mr. D. S. Mabry, who carried out the erythrophagocytic test, is gratefully acknowledged.

\section{Merwin Moskowitz}

Division of Bacteriology,

Department of Biological Sciences,

Purdue University, Lafayette, Indiana. Nov. 29.

${ }^{1}$ This is the 125-ml. size of a type of bottle in routine use for storing blood. Contained $40 \mathrm{ml}$. of $A C D$ solution of following compositions : $1.38 \mathrm{gm}$. dextrose, $1.24 \mathrm{gm}$. sodium citrate and oratories

${ }^{2}$ Wright, C. S., et al., J. Lab. and Clin. Med., 41, 169 (1953).

\section{Coagulation Mechanism of the Horse}

AN investigation has been made, by means of the newer coagulation tests, into the coagulation mechanism of horses' blood. As compared to human values, the most striking features are the greatly prolonged clotting time, poor clot retraction in spite of a platelet count within normal human limits and a prolonged one-stage prothrombin time.

Using the thromboplastin generation test ${ }^{1}$, the prolonged clotting time was found to be due to a deficiency of antihæmophilic globulin, and this defect was present in both sexes. The deficiency was corrected by normal human plasma. This finding may well prove a most useful tool for those investigating hæmophilia in man. 'The horse is the only known animal exhibiting this defect, which is a species difference of great interest. 